\section{ONOMÁVAEIN}

Revista semestral de lingüística, filología y traducción
PONTIFICIA UNIVERSIDAD CATÓLICA DE CHILE CATOLICA DE CHILE
FACULTAD DE LETRAS

\title{
Origin and diversity of the words for ancient Eurasian grain legumes in Slavic languages
}

\author{
Aleksandar Mikić \\ Institute of Field and Vegetable Crops / \\ University of Novi Sad \\ Serbia
}

ONOMÁZEIN 28 (diciembre de 2013): 280-287

DOI: 10.7764/onomazein.28.23

\section{(c) $\bigodot_{\mathrm{BY}} \bigodot_{\mathrm{ND}}$}

Aleksandar Mikić: Institute of Field and Vegetable Crops / Department of Field and Vegetable Crops, Faculty of Agriculture, University of Novi Sad. Serbia.

Correo electrónico: aleksandar.mikic@nsseme.com; aleksandar.mikic@ifvcns.ns.ac.rs 


\section{Abstract}

This short research note aims at demonstrating the importance of the role that grain legumes, such as pea (Pisum sativum L.), lentil (Lens culinaris Medik.) or field bean (Vicia faba L.), have been playing in the everyday lives of both modern Slavic nations and their ancestors. This role has been witnessed by rather rich lexicological evidence and supported by attested etymological connections. This note also links Slavic roots to the other members of Indo-European language families and presents their common ProtoIndo-European origins.

Keywords: etymology; field bean; lentil; lexicology; pea; Slavic languages. 


\section{Introduction}

The term grain legumes comprises all legume (fam. Fabaceae syn. Leguminosae) species that are grown for and are used in the form of either immature or mature grains for both human consumption and in animal feeding, as well as for various non-food purposes such as green manure (Ćupina et al., 2004). Crops such as pea (Pisum sativum L.), lentil (Lens culinaris Medik.), field bean (Vicia faba L.), vetchlings (Lathyrus spp.) and vetches (Vicia spp.) are considered the most significant on a world scale (Smýkal et al., 2010). All these species originated in Near Eastern, Mediterranean and Central Asian centres of diversity (Zeven \& Zhukovsky, 1975) and are also among the first domesticated plant species in the world (Zohary \& Hopf, 2000). The earliest archaeological findings of these crops are about 10,000 years old and are located mainly in Syria (Tanno \& Willcox, 2006). From there, they spread in all directions, especially towards Europe, where they and cereals carried out the "agricultural revolution" of post-glacial Europe. In a rather short period, during the sixth millennium BC, grain legumes reached almost every corner of the continent, such as northern France (Bakels, 1999) and Armenia (Hovsepyan \& Willcox, 2007). The Balkan Peninsula and Central Europe are especially rich in archaeobotanical evidence on the grain legume cultivation in Neolithic, as witnessed by sites such as Stare Gmajne in Slovenia (Tolar et al., 2010), Kutné Hory in Czech Republic (Smýkal \& Mikić, 2009) and southern Serbia (Medović et al., 2011).

The Slavic languages have the greatest number of speakers of all the branches of the IndoEuropean language family in Europe. Like its relatives, such as Baltic, Celtic, Hellenic, Italic or Germanic branches, the ultimate origin of the Slavic nations and their languages are ProtoIndo-Europeans, the people who spoke supposed Proto-Indo-European language and became distinct in the vast Pontic-Caspian steppe, from which they started to migrate in many direc- tions during the fifth millennium BC (Anthony, 2007). The Balto-Slavic branch got separated from other Indo-European languages probably from 3,000 to 1,000 BC (Andersen, 2003), while between 1,500 and 1,000 BC these two groups were finally differentiated from each other. The Slavs in their original homeland in East Europe were scarcely known to Greeks or Romans, but their remarkable expansion in early fourth century $A D$ made them more discernible to the Western civilisation. It is assumed that there was a language spoken by all Slavic tribes before their migration, directly derived from the Proto-Indo-European, and it is commonly referred to as Proto-Slavic. It is true that modern Slavic languages are rather differentiated, but their common underlying stratum is highly recognisable and the differences are still relatively small (Lockwood, 1977).

Like in other branches of the Indo-European language family, there is an extensive vocabulary of the words common to all Slavic languages, retaining nearly the same forms despite a millennium-and-a-half long geographic separation. Among these, especially notable are those related to animals and plants, particularly fruits, cereals and legumes (Mikić-Vragolić et al., 2007). Since the significant geographic proximity of both Proto-Indo-European and Proto-Slavic homelands with the routes of the domestication of the most ancient grain legumes, it may be assumed that the ancestors of the modern Slavic peoples knew rather well pea, lentil or field bean and that they both cultivated and used them before their great migrations. By this reason, the main goal of this preliminary research was to examine the origin and the diversity of the words denoting pea, lentil and field bean and in the majority of the modern Slavic languages.

\section{Words for pea in Slavic languages}

The words denoting pea in modern Slavic languages demonstrate a remarkable morphological uniformity (table 1). Only a slight modification occurs in some languages. In some of 
the languages of the southern branch, such as Croatian, Macedonian, and Serbian, the words have a diminutive form by adding the suffix -ak. A hypothetical change could have happened during the introduction of common bean (PhaseoI us vulgaris L.), since in Croatian and western dialects of Serbian it is called grah: due to the larger size of its seeds, it could adopt this name, while pea, in fact, began to be referred to as small grah, that is, grašak. In the languages of the eastern branch, such as Rusyn, it is -ok. It is interesting that in Russian goroshok denotes vetches (Vicia spp.). Both suffixes -ak and -ok reflect the ProtoSlavic *-ঙ kŭ.

The origin of the words denoting pea in all the Slavic languages is the Proto-Slavic root *gorhŭ, also denoting pea (Vasmer, 1953). This root, in its turn, might be derived from the Proto-Indo-European *ghArs-, ghers-2, denoting a leguminous plant in general (Pokorny, 1959; Nikolaev, 2007), but this reconstruction mostly remains hypothetical and, in contrast, could be explained as a borrowing from one of the neighbouring peoples (Mallory \& Adams, 2006). Precious evidence that essentially contributed to the assessment of the Proto-Slavic root is the word denoting pea in Polabian, an extinct Slavic language, gorch. From Slavic, its word denoting pea was borrowed by some neighbouring languages, such as Albanian, in the form of gróshë

\section{FIGURE 1}

A geographical presentation of the development of the words denoting pea, lentil and field bean in Slavic from their Proto-Indo-European roots and in some other branches of the Indo-European language family

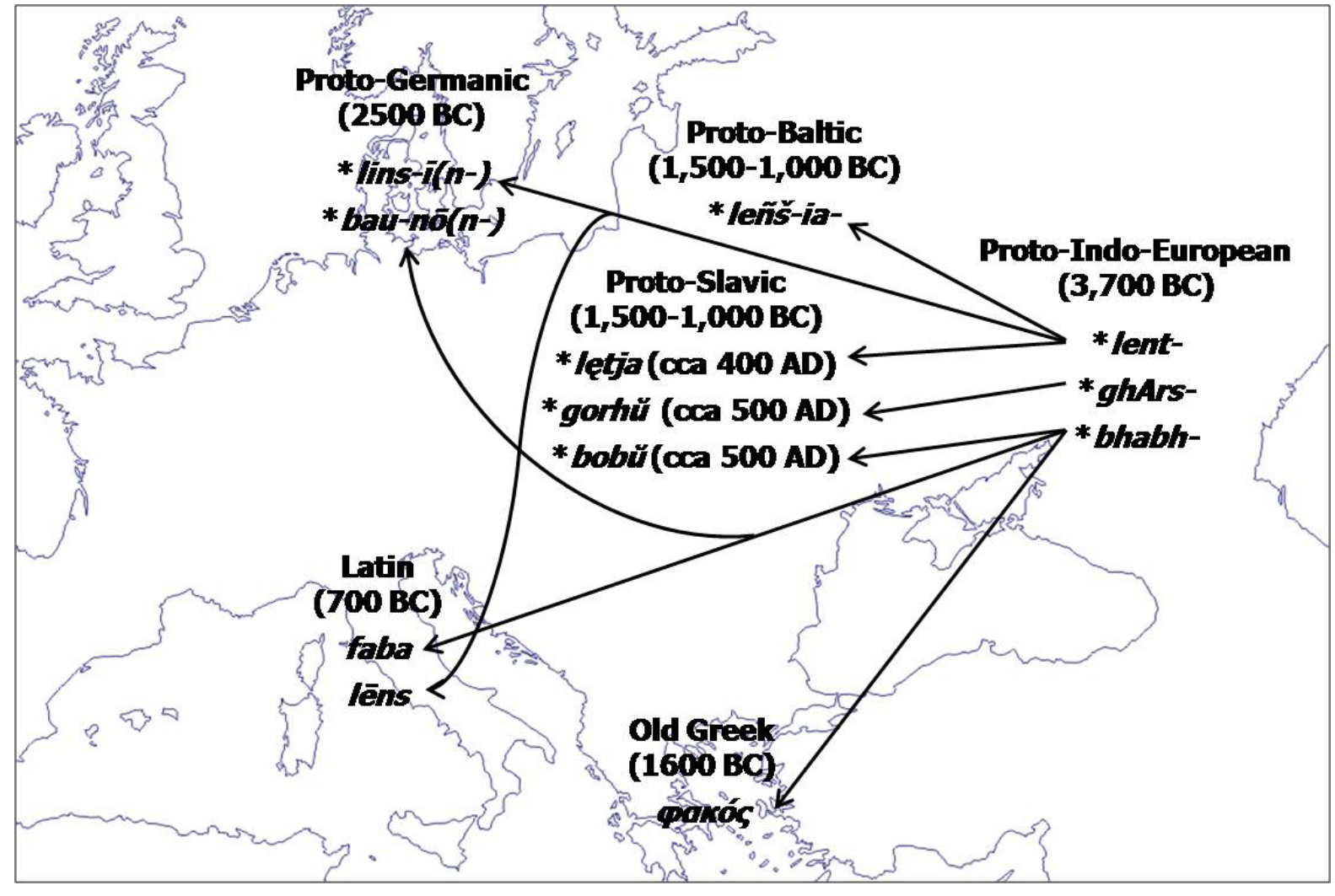

1 The dates on the map indicate either the time when the direct descendants of the Proto-Indo-European language are supposed to be developed or the time when their first records were attested. 
and meaning common bean, and Aromanian, as grãshac and with the preserved original Slavic meaning (Mikić, 2009).

The hypothetical Proto-Indo-European root *ghArs- was not preserved in the proto-languages of the other Indo-European languages (figure 1). In fact, its traces may be found only in the Baltic languages, such as Lithuanian, with gařšas and garšvà for the species Archangelica officinalis, and in Germanic languages, such as High German, with Giersch for the species Aegopodium podagraria (Vasmer, 1953).

\section{TABLE 1}

Words denoting pea in modern Slavic languages

\begin{tabular}{c|c} 
Language & Word \\
\hline Belarusian & garoh \\
\hline Bulgarian & grah \\
\hline Croatian & grašak \\
\hline Czech & hrách \\
\hline Kashubian & groch \\
\hline Lower Sorbian & groch \\
\hline Macedonian & grašok \\
\hline Polish & groch \\
\hline Russian & gorokh \\
\hline Rusyn & hraščk \\
\hline Serbian & grašak \\
\hline Slovak & hrach \\
\hline Slovenian & grah \\
\hline Ukrainian & gorokh \\
\hline UpperSorbian & hroch
\end{tabular}

\section{Words for lentil in Slavic languages}

It is notable that the words denoting lentil in the modern Slavic languages form two morphologically related groups. The first group, comprising languages like Bulgarian or Slovenian, owes the origin of its words for lentil directly to the Proto-Slavic *lętja (Vasmer, 1955) and ultimately to the Proto-Indo-European */ent-, *lent-s- (Pokorny, 1959; Nikolayev, 2007), both denoting lentil as well. In such form, the Slavic word for lentil was adopted by Hungarian as lencse (Skok, 1972) and, most likely, returned to Slavic languages in the form of the Rusyn lenča, since the preservation of the nasality is impossible in an inherited East Slavic item.

This Proto-Indo-European root also gave the words denoting lentil in other derivatives of it, such as the Proto-Baltic */eñš-ia-, Proto-Germanic *lins-ī(n-) or Latin lēns (figure 1 ), all of which produced words denoting the same in their modern descendants, such as Modern Lithuanian Ięšis, Modern German Linse or Modern Italian lenticchia. To the same group belongs the Russian local lyacha (Vasmer, 1955).

There are opinions that the words denoting lentil in another group of Slavic languages, such as the Czech čočka and the Serbian sočivo, were derived from the Proto-Slavic *sočevica (Vasmer, 1958). It is considered that this root could be somehow related to the Primitive Slavic *sokŭ (Derksen, 2008), because of the Sorbian sok (table 2), and the Primitive Indo-European ${ }^{*} s(w) O k^{w_{-}}$, both meaning juice (Nikolayev, 2007), but without any clarification yet.

\section{TABLE 2}

Words denoting lentil in modern Slavic languages

\begin{tabular}{c|c} 
Language & Word \\
\hline Belarusian & sačavica \\
\hline Bulgarian & leshta \\
\hline Croatian & leća \\
\hline Czech & čočka \\
\hline Lower Sorbian & sok \\
\hline Macedonian & lekja \\
\hline Polish & soczewica \\
\hline Russian & chechevitsa \\
\hline Rusyn & lenča \\
\hline Serbian & sočivo; leća \\
\hline Slovak & šošovica \\
\hline Slovenian & leča \\
\hline Ukrainian & sochevitsia \\
\hline Upper Sorbian & sok
\end{tabular}




\section{Words for field bean in Slavic languages}

Similarly to pea, the words denoting field bean in modern Slavic languages show almost the highest possible degree of mutual morphological similarity. Their common ancestor is the Proto-Slavic *bobŭ (Vasmer, 1953), that, in its turn, was derived from the Proto-Indo-European *bhabh-, bhabhā, also denoting field bean and meaning literally something swelling (Pokorny, 1959; Nikolaev, 2007). From Slavic, the word for field bean was borrowed by the neighbouring Romani as boba, Romanian as bob and Hungarian as bab (Mikić, 2011).

This Proto-Indo-European root also produced the supposed Proto-Albanian root *bhaka, the Old Prussian baba and babo, the Proto-Germanic *bau-nō(n-) and the Latin faba, all with the same, preserved original meaning. The only branch of the Indo-European language family where the meaning shifted from field bean to lentil is Old Greek, with yakós (Mikić, 2010).

\section{TABLE 3}

Words denoting field bean in modern Slavic languages

\begin{tabular}{c|c}
\hline Language & Word \\
\hline Belarusian & bob \\
\hline Bulgarian & bob \\
\hline Croatian & bob \\
\hline Czech & bob \\
\hline Kashubian & bób \\
\hline LowerSorbian & bob \\
\hline Macedonian & bob \\
\hline Polish & bób \\
\hline Russian & bob \\
\hline Rusyn & bob \\
\hline Serbian & bob \\
\hline Slovak & bob \\
\hline Slovenian & bob \\
\hline Ukrainian & bib \\
\hline UpperSorbian & bob
\end{tabular}

It is noteworthy that field bean had a kind of ethnobotanical significance for the Ancient Slavs and Romans, witnessed by personal names such as Boban, Boba and Bobana in Modern Serbian and Croatian languages (Skok, 1971) and the Latin names Fabius and Fabia (Pokorny, 1959).

\section{Conclusions}

By the attested high degree of morphological conservatism and a remarkable lexicological continuum throughout millennia, this brief lexicological and etymological thesaurus may be considered another testimony of the significant role the most ancient European grain legumes, such as pea, lentil and field bean, have been playing in the everyday life of the Slavic peoples. This preliminary research, with its results, may also be regarded as an invitation to crop historians and linguists to assist each other in solving the puzzling issues of our common Slavic and European past.

\section{Acknowledgements}

This research is a result of the projects TR31024 of the Ministry of Science and Technological Development of the Republic of Serbia and SEELEGUMES within SEE-ERA.NET Plus programme of the European Union.

\section{Bibliographic references}

Andersen, H., 2003: Language contacts in prehistory: studies in stratigraphy, Amsterdam: John Benjamins Publishing Company.

Anthony, D. W., 2007: The Horse, the Wheel, and Language: How Bronze-Age Riders from the Eurasian Steppes Shaped the Modern World, New Jersey: Princeton University Press.

BAKELS, C., 1999: "Archaeobotanical investigations in the Aisne valley, northern France, from the Neolithic up to the early Middle Ages", Vegetation History and Archaeobotany 8, 71-77.

Ćupina, B., P. ERIĆ, Đ. Krstić \& S. VuČKović, 2004: "Fo- 
rage catch crops in sustainable agriculture and organing farming", Acta Agriculturae Serbica 17 (special issue), 451-459.

Derksen, R., 2008: Etymological Dictionary of the Slavic Inherited Lexicon, Leiden/Boston: Brill.

Hovsepyan, R. \& G. Willcox, 2007: "The earliest finds of cultivated plants in Armenia: evidence from charred remains and crop processing residues in pisé from the Neolithic settlements of Aratashen and Aknashen", Vegetation History and Archaeobotany 17, 63-71.

Lockwood, W. B., 1977: Indo-European Philology, Historical and Comparative, London: Hutchinson.

Mallory, J. \& D. Adams, 2006: The Oxford Introduction to Proto-Indo-European and the Proto-IndoEuropean World, Oxford/New York: Oxford University Press.

Medović, A., A. Mikić, B. Ćupina, Ž. Jovanović, S. Radović, A. Nikolić \& N. Stanisavljević, 2011: "Pisum \& Ervilia Tetovac - Made in Early Iron Age Leskovac. Part One. Two charred pulse crop storages of the fortified hill fort settlement Hissar in Leskovac, south Serbia", Ratarstvo i povrtarstvo / Field and Vegetable Crops Research 48, 219-226.

MıKIĆ, A., 2009: "Words denoting pea (Pisum sativum) in European languages”, Pisum Genetics 41, 29-33.

Mıkić, A., 2010: "Words denoting lentil (Lens culinaris) in European languages", Journal of Lentil Research 4, 15-19.

MıкIĆ, A., 2011: "Words denoting faba bean (Vicia faba) in European languages", Ratarstvo i povrtarstvo / Field and Vegetable Crops Research 48, 233-238.

Mikić-VRagolić, M., A. Mikić, B. Ćupina, V. Mihailović, S. VASILJEVIĆ, Đ. KRSTIĆ \& M. VASIĆ, 2007: "Words related to some annual legumes in Slavic and other Indo-European languages", Ratarstvo i povrtarstvo / Field and Vegetable Crops Research 44/II, 91-96.
Nikolayev, S. L., 2007: Indo-European Etymology. The Tower of Babel, an International Etymological Database Project [http://starling.rinet.ru].

Pokorny, J., 1959: Indogermanisches Etymologisches Wörterbuch, Bern: Francke.

Skok, P., 1971: Etimologijski rječnik hrvatskoga ili srpskoga jezika, I (A - J), Zagreb: JAZU.

Skok, P., 1972: Etimologijski rječnik hrvatskoga ili srpskoga jezika, $2\left(K-\right.$ Poni $\left.^{2}\right)$, Zagreb: JAZU.

SmÝKAL, P. \& A. Mikić, 2009: "Historie pěštování luskovin v Evropě”, Uroda 11, 41-43

Smýkal, P., G. Kenicer, A. J. Flavell, J. Corander, O. Kosterin, R. J. Redden, R. Ford, C. J. Coyne, N. Maxted, M. J. Ambrose \& T. H. N. Ellis, 2010: "Phylogeny, phylogeography and genetic diversity of the Pisum genus", Plant Genetic Resources. doi:10.1017/ S147926211000033X

TAnno, K. \& G. Willcox, 2006: "The origins of cultivation of Cicer arietinum L. and Vicia faba L.: early finds from Tell el-Kerkh, north-west Syria, late 10th millennium B.P.", Vegetation History and Archaeobotany 15, 197-204.

Tolar, T., S. Jacomet, A. Veluš̌ek \& K. Čufar, 2010: “Recovery techniques for waterlogged archaeological sediments: a comparison of different treatment methods for samples from Neolithic lake shore settlements", Vegetation History and Archaeobotany 19, 53-67.

VASMER, M, 1953: Russisches etymologisches Wörterbuch, I $(A-K)$, Heidelberg: Carl Winters Universitätsverlag

VASMER, M., 1955: Russisches etymologisches Wörterbuch, 2 (L - Ssuda), Heidelberg: Carl Winters Universitätsverlag.

VASMER, M., 1958: Russisches etymologisches Wörterbuch, $3($ Sta $-Y)$, Heidelberg: Carl Winters Universitätsverlag.

Zeven, A. C. \& P. M. Zhukovsky, 1975: Dictionary of Cultivated Plants and Their Centres of Diversity, 
Wageningen: Centre for Agricultural Publishing and Documentation.

Zohary, D. \& M. Hopf, 2000: Domestication of Plants in the Old World: the Origin and Spread of Cultivated Plants in West Asia, Europe and the Nile Valley, Oxford: Oxford University Press. 